\title{
The Economic Determinants of Budget Deficits in South Africa
}

\author{
Genius Murwirapachena \\ Department of Economics, University of Fort Hare \\ Email: murwiragenius@gmail.com
}

\author{
Andrew Maredza \\ School of Economic \& Decision Sciences, North West University, South Africa \\ Email: (Corresponding Author) Andrew.Maredza@nwu.ac.za \\ Ireen Choga \\ School of Economic \& Decision Sciences, North West University, South Africa \\ Email: Ireen.Choga@nwu.ac.za
}

\section{Doi:10.5901/mjss.2013.v4n13p561}

\begin{abstract}
Since 1980, South Africa recorded massive budget deficits except in 2007 and 2008 when the budget surpluses as a percentage of GDP respectively stood at 0.3 per cent and 0.7 per cent. This stirred a great debate on whether budget deficits in South Africa are a result of poor governance or are due to the magnitude of the economic problems that the government seeks to alleviate. Therefore, this study examines the economic determinants of budget deficits in South Africa for the period 1980 - 2010. Specifically, the study seeks to ascertain if budget deficits in South Africa are a result of the fight against economic problems. The Vector Error Correction Model (VECM) was used to determine the impact of selected macroeconomic variables on budget deficits in South Africa. The results revealed that all the determinants have a positive impact on budget deficits except for foreign debt. However, foreign reserves explain the largest component variation of budget deficit followed by foreign debt, unemployment, economic growth and government investment, in that order.
\end{abstract}

Keywords: Economic Determinants, Budget Deficit, South Africa, Vector Error Correction.

\section{Introduction}

Budget deficits were at the forefront of macroeconomic adjustment policies in the 1980s and 1990s in both developing and industrial countries (Jacobs, Schoeman and van Heerden, 2000). According to Easterly and Schmidt-Hebbel (1994), budget deficits occupied a centre stage in the massive reform programs which were initiated in many developing countries on all continents. The South African government, being the custodian of economic welfare has also since 1980 embarked on massive spending sprees in a bid to achieve Pareto optimality. This has seen the budget deficit as a percentage of GDP averaging about 2.8 per cent for the period 1980 to 2010 (DTI, 2011). The particular framework was adopted following the Keynesian maxim which radiates that without the government taking a more active role to steer the economy, countries could lurch from unstable growth to deep and prolonged recessions. A more expansionary fiscal policy framework characterised by consecutive budget deficits has therefore dominated in South Africa over the years (National Treasury, 2011). Economic phenomena such as unemployment, levels of economic growth, foreign debt, foreign reserves and government investment in infrastructural development have significantly determined the level of the budget deficit in South Africa.

The determinants and role of budget deficits have always been debated, however yielding assorted conclusions. Among those who contributed to the role played by budget deficits is Hobbes (1651) who credited the government as the solitary provider of a decent life. This was further supported by Keynes (1936) who argued that without the government, economies would fail. Kustepeli (2005) supported the work of Hobbes (1651) and Keynes (1936) by pointing out that large governments are good for economic performance. Other economists who thrust their belief in fiscal policy include Musgrave (1959) who argued that the government always uses the fiscal policy framework to improve social welfare. Contrary to these, economists ranging from classical to those holding the public choice view argued against the use of 
budget deficits to improve economic performance. In particular, Smith (1776), Ricardo (1817) and Pigou (1912) suggested that instabilities in the economy are a result of government interferences.

Following the controversy regarding budget deficits, this study examines the economic determinants of budget deficit in South Africa. Specifically, the study seeks to ascertain if budget deficits in South Africa are a result of the fight against economic problems. Selective attention is given to particular economic variables which are: unemployment, economic growth, foreign debt, foreign reserves and government investment expenditure. The study seeks to contribute to the on-going debate on whether budget deficits in South Africa are a result of inefficiency and poor governance or they are due to the magnitude of the economic problems that the government seeks to alleviate. There is hardly any literature regarding the determinants of budget deficits in South Africa and the developing world, therefore, this study will contribute to the little existing literature concerning the controversial phenomena.

The structure of this paper is as follows: section two provides a brief overview of budget deficits and selected macro-economic variables in South Africa over the study period. Section three of the study reviews the relevant literature while the methodology adopted for the estimation and data issues are presented in section four. Section five provides for the outcomes of the estimations and conclusions are presented in section six.

\section{An Overview of Budget Deficits and Selected Economic Variables in South Africa}

For the period 1980 to 2010 the South African fiscal trends recorded massive budget deficits except in 2007 and 2008 when the government recorded respective budget surpluses of R22 777 million and R34 400 million (National Treasury, 2011). Budget deficit as a percentage of GDP increased from a minimum of 1.3 per cent in 1980 to about 4.8 per cent in 2010 with 6.8 per cent recorded in 1993 being the highest figure of the period (DTI, 2011). In 2007 and 2008 when the treasury recorded its surpluses for the period, budget surplus as a percentage of GDP respectively stood at 0.3 per cent and 0.7 per cent. The National Treasury (2011) blamed high levels of unemployment, low growth performances, among other macroeconomic problems for the budget deficits recorded over the period.

The unemployment rate hovered at an average of 21.7 per cent over the period, rising from 9.8 per cent in 1980 to 26.1 per cent in 2010 (StatSA, 2011). Additionally, Banerjee, Galiani, Levinsohn, McLaren and Woolard (2008) identified the 6.1 per cent recorded in 1981 as the lowest unemployment rate and the 30.4 per cent recorded in 2002 as the highest rate in the period. Economic growth rates have also been equally disappointing in South Africa. The National Treasury (2011) confirmed the statement of Du Plessis and Smit (2007) that economic growth in South Africa could not maintain buoyancy in government revenue, except in 2007 and 2008 when the treasury recorded its two ever surpluses of the period. Capital expenditure has also contributed to budget deficits in South Africa. It increased from R4 002 million in 1980 to R80 819 million in 2010, averaging R24 753 million per year over the thirty years (DTI, 2011). Turbulences in foreign exchange reserves and the foreign debt also hugely contributed to the persistent budget deficits in South Africa over the period 1980 to 2010. Trends in budget deficits and selected macro-economic variables are presented in Table 1.

Table 1: Trends in budget deficits and selected macro-economic variables $(1980-2010)$

\begin{tabular}{lcccccc}
\hline \multicolumn{1}{c}{ Average } & $1980-84$ & $1985-89$ & $1990-94$ & $1995-99$ & $2000-04$ & $2005-10$ \\
\hline Deficit as a \% of GDP & $-2.2 \%$ & $-3.3 \%$ & $-4.3 \%$ & $-4.0 \%$ & $-1.6 \%$ & $-1.6 \%$ \\
Unemployment rate & $10.5 \%$ & $22.3 \%$ & $21.2 \%$ & $22.4 \%$ & $28.0 \%$ & $25.1 \%$ \\
Economic growth rate & $1.4 \%$ & $1.7 \%$ & $0.9 \%$ & $2.8 \%$ & $3.8 \%$ & $3.2 \%$ \\
Foreign debt (R m) & 26454 & 54979 & 81383 & 188995 & 293049 & 524198 \\
Foreign reserves (R m) & 540 & 1429 & 3498 & 20530 & 57473 & 212883 \\
Capital formation (R m) & 46925 & 36558 & 26620 & 28166 & 32573 & 52149 \\
\hline
\end{tabular}

Source: Own computations with data from the DTI (2011)

Table 1 show that the period 1990 to 1994 recorded the highest average budget deficit of 4.3 per cent. This was mainly due to the 6.8 per cent deficit recorded in 1993 which was a result of government spending towards the first all-inclusive democratic elections, among other reasons. Though the unemployment rate also exponentially increased between 1980 and 2010, averages of the variable were inconsistent. Economic growth and capital formation averages were inconsistent while foreign debt and foreign reserves averages exponentially grew over the period. 


\section{An Overview of Literature}

The body of theoretical literature regarding the determinants and role of budget deficits can be traced back to as far as 1600s when Hobbes (1651) credited the government as the solitary provider of a decent life. Subsequently, Keynes (1936) in agreement to the work of Hobbes (1651) stressed that without the government taking a more active role, economies would fail as was evidenced in the Great Depression of 1930. In support of the work of Hobbes (1651) and Keynes (1936), Kustepeli (2005) pointed out with great emphasis that large governments are good for economic performance. All these theorists formed the basis of the fiscal policy theory by Musgrave (1959) who argued that the government always uses the fiscal policy framework to improve social welfare. However, economic theorists spanning from classical to those holding the public choice view argued against the use of budget deficits to improve economic performance. In particular, Smith (1776), Ricardo (1817) and Pigou (1912) suggested that instabilities in the economy are a result of government interferences. In solidarity to the classical dictates, Buchanan and Tullock (1962) added that policy makers use the fiscal policy framework to maximise their personal welfare and utility rather than social welfare.

Several studies regarding budget deficits have been conducted by previous researchers. Arora and Dua (1993), Saleh (1996), Akinboade (2004), Bayar, and Smeets (2009) as well as Agnello, and Sousa (2009)examined budget deficits in the developed countries. These researchers used different data sets and applied different econometric methods, and therefore discovered assorted results. Researches on budget deficits in developing countries include the work of Premchand (1984), Alogoskoufis and Ploeg (1991), Easterly, Rodriguez and Schmidt-Hebbel (1994) and Makinen (2005). Similar to researches in developed countries, assorted results were also realised due to differences in data sets, methodologies and countries of study. Researches by Jacobs, Schoeman and van Heerden (2000) and Fedderke, Perkins and Luiz (2006) respectively examined budget deficits and its determinants in South Africa.

\section{Methodology}

The study adopts a vector autoregression (VAR) model to estimate the determinants of budget deficits in South Africa. Initially, the data is tested for stationarity using the Dickey-Fuller and the Augmented-Dickey Fuller unit root tests. Subsequently, the Johansen $(1991,1995)$ cointegration technique is used to test for cointegration. Afterwards, a vector error correction model (VECM) is employed to estimate the long run equation and the existence of error correction. Diagnostic checks are also performed to test for normality (Jarque-Bera), heteroskedacity (White test) and serial correlation (Lagrange Multiplier). Finally, impulse response analysis and variance decomposition are performed to respectively examine the relation between budget deficit and the selected economic variables; and the proportion of forecast error variance in a variable that is explained by innovations in itself and the other variables.

\section{Empirical Model Specification}

This study adopted the model used by Roubini, Sachs, Honkapohja and Cohen(1989) as explained by Bayar and Smeets (2009) who used time-series cross-section regressions to investigate the economic, political and institutional determinants of budget deficits in the European Union. The model is modified to investigate the economic determinants of budget deficits in South Africa. Budget deficits are modelled as a function of selected macroeconomic variables. This is expressed as follows:

$$
B D_{t}=\beta_{0}+\beta_{1} U N E M P_{t}+\beta_{2} G D P_{t}+\beta_{3} \text { FOREV }_{t}+\beta_{4} \text { FODET }_{t}+\beta_{5} \text { GOVIN }_{t}+\varepsilon_{t} \cdots
$$

In order to avoid any form of misconception of empirical results, a description of all variables that appear in the estimated equation is provided. All the explanatory variables are converted to logarithms so as to remove trends. The dependent variable (budget deficit) is not converted into natural logs because its data contains negative values. The model (in equation 1) thus assumes the form:

$$
B D=\beta_{0}+\beta_{1} L U N E M P_{t}+\beta_{2} L G D P_{t}+\beta_{3} L F O R E V_{t}+\beta_{4} L F O D E T_{t}+\beta_{5} L G O V I N_{t}+\varepsilon .
$$

Where

$\mathrm{BD}=$ Budget deficit as a percentage of GDP,

LUNEMP = Logarithm of unemployment based on the strict definition unemployment rate, 
LGOVIN = Logarithm of gross fixed capital formation used as proxy for government investment,

LFOREV = Logarithm of foreign exchange reserves,

LGDP = Logarithm of economic growth (GDP in R million),

LFODET = Logarithm of total foreign debt and,

$\varepsilon=$ the error term.

\subsection{Data issues}

This study employs annual time series data covering the period 1980 to 2010. Data on all variables is obtained from the electronic database of the Department of Trade and Industry (DTI). All the data series were tested for stationarity to avoid the possibility of drawing conclusions based on statistically spurious relationships. The Dickey-Fuller and the Augmented Dickey-Fuller unit root tests were used and test results are presented in Table 2.

Table 2: Tests for Stationarity

\begin{tabular}{|c|c|c|c|c|c|c|}
\hline & & & ickey-Fuller & & Augmented Di & ckey-Fuller \\
\hline Order of integration & Variable & Intercept & Trend and intercept & Intercept & Trend and intercept & No trend and no intercept \\
\hline Level & $\mathrm{BD}$ & $-2.242^{\star \star}$ & -2.324 & -2.303 & -2.320 & -0.886 \\
\hline $1^{\text {st }}$ Diff & $\mathrm{BD}$ & $-5.147^{* \star *}$ & $-5.166^{\star \star *}$ & $-4.122^{* \star \star}$ & $-3.996^{\star *}$ & $-4.214^{\star \star *}$ \\
\hline Level & LUNEMP & -1.499 & -2.333 & -2.330 & -2.371 & 0.567 \\
\hline $1^{\text {st }}$ Diff & DLUNEMP & -1.497 & -5.430 *** & $-5.961^{\star \star \star}$ & $6.414^{\star \star \star}$ & $-5.774^{\star \star \star}$ \\
\hline Level & LGDP & 1.100 & -1.629 & 1.603 & -1.716 & $2.646^{\star \star \star}$ \\
\hline 1st Diff & DLGDP & $-3.562^{* \star *}$ & $-4.334^{\star * \star}$ & $-4.031^{* \star *}$ & $-4.415^{\star \star \star}$ & $-2.797^{* * *}$ \\
\hline Level & LFOREV & 0.179 & $-4.148^{* * *}$ & -0.108 & $-4.262^{\star *}$ & $3.497^{\star \star \star}$ \\
\hline $1^{\text {st }}$ Diff & DLFOREV & $-9.135^{\star \star \star}$ & $-9.132^{\star \star \star}$ & $-9.000^{* * *}$ & $-8.846^{\star \star *}$ & $-6.804^{* * *}$ \\
\hline Level & LFODET & 0.220 & -2.600 & \begin{tabular}{|l|}
-1.718 \\
\end{tabular} & -3.118 & $3.674^{\star \star \star}$ \\
\hline 1st Diff & DLFODET & $-3.867^{\star \star \star}$ & $-4.354^{\star * \star}$ & $-4.352^{\star \star \star}$ & $-4.308^{\star \star \star}$ & $-3.416^{\star \star *}$ \\
\hline Level & LGOVIN & $-1.787^{\star}$ & -2.101 & -2.112 & -2.036 & -0.248 \\
\hline $1^{\text {st }}$ Diff & DLGOVIN & $-2.772^{\star \star \star}$ & $-3.126^{*}$ & $-2.944^{*}$ & $-4.227^{\text {** }}$ & $-3.034^{\star \star \star}$ \\
\hline $1 \%$ *** & & -2.644 & -3.770 & -3.670 & -4.297 & -2.644 \\
\hline $5 \%$ ** & & -1.953 & -3.190 & -2.964 & -3.568 & -1.952 \\
\hline $10 \% *$ & & -1.610 & -2.890 & -2.621 & -3.218 & -1.610 \\
\hline
\end{tabular}

*** represents stationary at $1 \%$ level of significance, ${ }^{* *}$ represents stationary at $5 \%$ level of significance, ${ }^{*}$ represents stationary at $10 \%$ level of significance, L represents Logarithms of variables, D represents that the variable has been differenced.

The Dickey-Fuller results from Table 2 suggest that the null hypothesis of the presence of unit root in the variables in levels could not be rejected at $1 \%$ level of significance indicating that the variables are non-stationary in levels. However, when the variables are first differenced the null hypothesis of the unit root in each of the series was rejected at the $1 \%$ significancelevel. The much stricter Augmented Dickey-Fuller also revealed that the null hypothesis of unit root in each of the series was rejected at $1 \%$ significance level only after the variables are first differenced. Therefore it can be suggested that all the variables are integrated of order one, I (1).

\subsection{Main Findings}

Since it is established that the variables are integrated of the same order, cointegration tests are performed to determine the existence of a long-run equilibrium relationship amongst the variables. One lag was selected using the lag order selection criteria. Cointegration of variables means that the linear combination of the variables is stationary even though the individual variables will be non-stationary. The Johansen's $(1991,1995)$ maximum likelihood approach was used to test for cointegration.

Testing for cointegration using a model with many variables is cumbersome for researchers. Therefore, this study used the pair-wise correlation matrix to guide the variable selection exercise. Table 3 shows results for the pair-wise correlation matrix used to determine the exact relationship between the six variables involved in this study. 
Table 3: Pair-wise correlation matrix

\begin{tabular}{|l|c|c|c|c|c|c|}
\hline & BD & LUNEMP & LGDP & LFOREV & LFODET & LGOVIN \\
\hline DFCT & 1.000 & 0.025 & 0.315 & 0.270 & 0.168 & 0.427 \\
\hline UNEMP & 0.025 & 1.000 & 0.571 & 0.669 & 0.751 & -0.291 \\
\hline GDP & 0.315 & 0.571 & 1.000 & 0.956 & 0.924 & 0.382 \\
\hline FOREV & 0.270 & 0.669 & 0.956 & 1.000 & 0.964 & 0.157 \\
\hline FODET & 0.168 & 0.751 & 0.924 & 0.964 & 1.000 & 0.070 \\
\hline GOVIN & 0.427 & -0.291 & 0.382 & 0.157 & 0.070 & 1.000 \\
\hline
\end{tabular}

Correlation results from Table 3 showed that all the explanatory variables are positively correlated with budget deficits. This means that high values of the explanatory variables are likely to be associated with high values of budget deficits in South Africa.

This study used the Johansen technique which requires an indication of the lag order and the deterministic trend assumption of the VAR. To select the lag order for the VAR, the information criteria approach is applied as a direction in choosing the lag order. In this study, the selection is made using a maximum of 3 lags in order to permit adjustment in the model and accomplish well behaved residuals. Lag length selection criteria results are presented in Table 4 which showed that all the criteria except for the Akaike information criteria (AIC) selected $1 \mathrm{lag}$. The agreement by most of the criteria leads to the adoption of $1 \mathrm{lag}$. Subsequently, the Johansen cointegration test is therefore conducted using 1 lag for the VAR.

Table 4: Lag order selection criteria

\begin{tabular}{|c|c|c|c|c|c|c|}
\hline Lag & LogL & LR & FPE & AIC & SC & HQ \\
\hline 0 & 70.52442 & NA & $4.71 \mathrm{e}-10$ & -4.449960 & -4.167071 & -4.361363 \\
\hline 1 & 240.3913 & $257.7291^{*}$ & $4.88 \mathrm{e}-14^{*}$ & -13.68216 & $-11.70194^{*}$ & $-13.06198^{*}$ \\
\hline 2 & 280.0285 & 43.73751 & $5.40 \mathrm{e}-14$ & $-13.93300^{*}$ & -10.25544 & -12.78123 \\
\hline * indicates lag order selected by the criterion, LR: sequential modified LR test statistic (each test at 5\% level) \\
FPE: Final prediction error, AIC: Akaike information criteria, SC: Schwarz information criteria, HQ: Hannan-Quinn information criteria \\
\hline
\end{tabular}

Both the Johansen trace (Table 5) and maximum-eigenvalue (Table 6) cointegration rank tests reflected that at least one cointegrating equation exist at $5 \%$ significance level. The null hypothesis of no cointegrating vectors is rejected since the trace (test) statistic of 112.74 is greater than the critical value of approximately 95.75 ; and the maximum eigenvalue of approximately 57.77 is greater than the critical value of approximately 40.08 at $5 \%$ significance level.

Table 5: Cointegration Rank Test (Trace)

\begin{tabular}{|c|c|c|c|c|}
\hline Hypothesized No. of CE(s) & Eigenvalue & Trace Statistic & 0.05 Critical Value & Prob. ${ }^{* *}$ \\
\hline None $^{*}$ & 0.863592 & 112.7426 & 95.75366 & 0.0020 \\
\hline At most 1 & 0.589192 & 54.97168 & 69.81889 & 0.4202 \\
\hline At most 2 & 0.346581 & 29.17244 & 47.85613 & 0.7601 \\
\hline At most 3 & 0.235933 & 16.83187 & 29.79707 & 0.6525 \\
\hline At most 4 & 0.169422 & 9.027977 & 15.49471 & 0.3628 \\
\hline At most 5 & 0.118099 & 3.644592 & 3.841466 & 0.0562 \\
\hline
\end{tabular}

Trace test indicates 1 cointegrating eqn(s) at the 0.05 level, ${ }^{*}$ denotes rejection of the hypothesis at the 0.05 level, ${ }^{*}$ MacKinnon-Haug-Michelis (1999) p-value

Table 6: Cointegration Rank Test (Maximum-Eigenvalue)

\begin{tabular}{|c|c|c|c|c|}
\hline Hypothesized No. of CE(s) & Eigenvalue & Max-Eigen Statistic & 0.05 Critical Value & Prob.** \\
\hline None * & 0.863592 & 57.77096 & 40.07757 & 0.0002 \\
\hline At most 1 & 0.589192 & 25.79924 & 33.87687 & 0.3331 \\
\hline At most 2 & 0.346581 & 12.34056 & 27.58434 & 0.9181 \\
\hline At most 3 & 0.235933 & 7.803895 & 21.13162 & 0.9153 \\
\hline At most 4 & 0.169422 & 5.383386 & 14.26460 & 0.6929 \\
\hline At most 5 & 0.118099 & 3.644592 & 3.841466 & 0.0562 \\
\hline
\end{tabular}

Using the same explanation, the null hypothesis that there is at most 1 cointegrating vector cannot be rejected. 
Therefore, it can be concluded that there is one significant long run relationship between the given variables. Since variables can either have short or long run effects, then a vector error correction model (VECM) is used to disaggregate these effects.

The VECM allows us to distinguish between the long and short run impacts of variables so as to establish the extent of influence that the economic (explanatory) variables have on budget deficits. The long run impact of the economic variables on budget deficits in South Africa as shown in Table 7 is illustrated using equation 3 :

Table 7: Normalised Cointegration equation: BD

\begin{tabular}{|c|c|c|c|}
\hline Variable & Coefficient & Standard error & t-statistic \\
\hline UNEMP(-1) & -21.527 & 2.125 & $-10.131^{\text {** }}$ \\
\hline GDP(-1) & 35.096 & 10.218 & 3.435 \\
\hline FOREV(-1) & -10.156 & 1.016 & -9.992 \\
\hline FODET(-1) & 18.287 & 1.682 & 10.870 \\
\hline GOVIN(-1) & -12.384 & 2.301 & -5.382 \\
\hline * and ** denotes significance at 0.05 and 0.01 level respectively \\
\hline
\end{tabular}

$$
B D_{t}=17897-21.52 \text { UNEMP+35.09GDP-10.15FOREY+18.28FODET-1238GOVIN+ }+\varepsilon_{t} \ldots . . .(3)
$$

The long run relationship between the variables as explained by equation 3 shows that UNEMP, FOREV and GOVIN have a negative long run relationship with BD; while GDP and FODET have a positive long run relationship with $\mathrm{BD}$. All the explanatory variables are statistically significant in explaining budget deficits in South Africa since they have absolute t-values that are greater than 2. The VECM results suggest that in the long run, a unit increase in UNEMP reduces the budget deficit by approximately $21.5 \%$ while a unit increase in GDP increases the budget deficit by approximately $35.1 \%$. Furthermore, the results suggest that a unit increase in FOREV reduces the budget deficit by approximately 10.2\%; while a unit increase in FODET increases the budget deficit by approximately $18.3 \%$ and a unit increase in GOVIN reduces the budget deficit by approximately $12.4 \%$. However, it is imperative to note that some of the relationships suggested by the long run equation are not compatible with theory, because the equation has wrong signs for some of the variables.

Additionally, the VECM results suggested evidence of error correction as shown in Table 8.

Table 8: Error correction results: BD

\begin{tabular}{|c|c|c|c|}
\hline Variable & Coefficient & Standard error & t-statistic \\
\hline CointEq1 & -0.694 & 0.2312 & $-3.0013^{\star *}$ \\
\hline $\mathrm{D}(\mathrm{BD})$ & -0.00152 & 0.2386 & -0.00636 \\
\hline $\mathrm{D}(\mathrm{UNEMP})$ & 1.9312 & 4.3717 & 0.4418 \\
\hline $\mathrm{D}(\mathrm{GDP})$ & 86.0694 & 53.8763 & 1.5975 \\
\hline $\mathrm{D}(\mathrm{FOREV})$ & -3.1611 & 2.1742 & -1.4539 \\
\hline $\mathrm{D}(\mathrm{FODET})$ & 15.7815 & 5.7873 & $2.7269^{*}$ \\
\hline $\mathrm{D}(\mathrm{GOV} / \mathrm{N})$ & -0.6381 & 10.1166 & -0.0631 \\
\hline Constant & -1.5553 & 0.6812 & $-2.2834^{\star}$ \\
\hline${ }^{*}$ and ${ }^{*}$ denotes significance at 0.05 and 0.01 level respectively \\
\hline \multicolumn{4}{|l}{}
\end{tabular}

The coefficient of the dependent variable $(-0.694)$ is statistically significant with a t-value of approximately -3.001 . This shows that the speed of adjustment is approximately 69.4\%; implying that if there is a deviation from equilibrium, approximately $69.4 \%$ of the budget deficit is corrected in one year as the variable moves towards restoring equilibrium. Therefore, this means that there is no strong pressure on budget deficit to restore long run equilibrium whenever there is a disturbance.

Diagnostic checks were performed so as to validate the parameter evaluation of the outcomes achieved by the model used in this study. The fitness of the model was tested in three main ways, that is, the langrage multiplier (LM) test for serial correlation, the White test for heteroscedasticity and the Jarque-Bera for normality test. Results presented in Table 9 suggested that there is no serial correlation, there is no conditional heteroscedasticity, and there is a normal distribution in the budget deficit model. 
Table 9: Diagnostic checks results

\begin{tabular}{|l|l|c|c|}
\hline \multicolumn{1}{|c|}{ Test } & \multicolumn{1}{c|}{ Null Hypothesis } & t-Statistic & Probability \\
\hline Langrage Multiplier (LM) & No serial correlation & 26.704 & 0.870 \\
\hline White (CH-sq) & No conditional heteroscedasticity & 301.849 & 0.364 \\
\hline Jarque-Bera (JB) & There is a normal distribution & 14.522 & 0.269 \\
\hline
\end{tabular}

According to Blanchard (1987) and Gujarati (1995), it is not necessary to give detailed explanations of the individual coefficients and their signs and significance because they are likely to be inaccurate. Blanchard (1987) pointed out that one should concentrate on commenting on conclusions about the whole model and thus emphasis should be placed on Impulse Response and Variance Decomposition functions which provide useful econometric inferences about the whole system of equations and exhaust the description of the dynamic properties of that system. Therefore, the study does not dwell on commenting on the results of the individual coefficients from the VAR model in the spirit of both Blanchard (1987) and Gujarati (1995) and as such proceeds to the Impulse Response and Variance Decompositions functions.

Since this study focuses on the determinants of budget deficits, only the impulse responses of budget deficits to the economic variables are reported. Impulse response functions in Appendix Figure 1 show the dynamic response of budget deficits to a one-period standard deviation shock to the innovations of the system and also indicate the directions and persistence of the response to each of the shocks over a 10 year period. The functions have the expected pattern and shocks to all the economic variables are significant although they are not persistent.

A one-period standard deviation shock to UNEMP marginally appreciates the budget deficit by about 5 per cent in 2 years before depreciating it by about 2 per cent, however the impact dies off in the $5^{\text {th }}$ year when it levels off. Additionally, a one-period standard deviation shock to GDP marginally appreciates the budget deficit by about 4 per cent in 2 years before depreciating it by about 3 per cent in the $4^{\text {th }}$ year; and levels off in the $6^{\text {th }}$ year. Furthermore, a one period standard deviation shock to FOREV appreciates the budget deficit by about 10 per cent, before depreciating it by about 5 per cent in the $5^{\text {th }}$ year and levels off in about 7 years. A one-period standard deviation shock to FODET appreciates the budget deficit by about 3 per cent for 2 years before depreciating it by about 7 per cent in the $4^{\text {th }}$ year. It further appreciates the budget deficit by about 2 per cent until it levels off in the $6^{\text {th }}$ year. However, a one-period standard deviation shock to GOVIN slightly appreciates the budget deficit by about 2 per cent before it quickly levels off in about 2 years. These results are compatible with economic theory.

Variance decomposition analysis is also performed to determine the relative importance of shocks in explaining variations in the variable of interest. In the context of this study, variance decomposition analysis provides a way of determining the relative importance of shocks to each of the economic determinants of budget deficits in explaining variations in the budget deficits. The results of the variance decomposition analysis which show the proportion of the forecast error variance in budget deficits explained by its own innovations and innovations in its economic determinants are presented in Table 10. This study reports only the variance decomposition in budget deficits and analyses the relative importance of each of its economic determinants in influencing its movements.

Table 10: Variance decomposition of DFCT

\begin{tabular}{|c|c|c|c|c|c|c|c|}
\hline Period & S.E & DFCT & UNEMP & GDP & FOREV & FODET & GOVIN \\
\hline 1 & 1.408334 & 100.0000 & 0.000000 & 0.000000 & 0.000000 & 0.000000 & 0.000000 \\
\hline 2 & 2.145088 & 83.23199 & 3.543789 & 2.367419 & 9.212823 & 1.077452 & 0.566528 \\
\hline 3 & 2.709049 & 73.78519 & 4.792886 & 2.181374 & 16.66321 & 2.011425 & 0.565914 \\
\hline 4 & 3.149124 & 70.46066 & 4.499890 & 1.656833 & 17.57474 & 5.148964 & 0.658906 \\
\hline 5 & 3.486837 & 70.74733 & 4.040354 & 1.409131 & 17.04318 & 6.033472 & 0.726531 \\
\hline 6 & 3.800115 & 71.31413 & 3.838499 & 1.436668 & 16.76069 & 5.855011 & 0.794998 \\
\hline 7 & 4.111318 & 70.98361 & 3.814593 & 1.499095 & 17.11388 & 5.762088 & 0.826731 \\
\hline 8 & 4.403751 & 70.48200 & 3.785007 & 1.487975 & 17.38994 & 6.003234 & 0.851845 \\
\hline 9 & 4.672002 & 70.24876 & 3.708564 & 1.449302 & 17.46106 & 6.261164 & 0.871155 \\
\hline 10 & 4.921952 & 70.21842 & 3.639901 & 1.437373 & 17.44180 & 6.371858 & 0.890652 \\
\hline
\end{tabular}

The study allows the variance decompositions for 10 years in order to ascertain the effects when the explanatory variables are allowed to affect the budget deficit for a relatively longer time. In the first year, all of the variance in budget deficits is explained by its own innovations (shocks), as suggested in Brooks (2002). For the $5^{\text {th }}$ year ahead forecast error 
variance reported in column 2 of Table 9 under S.E., the budget deficit itself explains about 71 per cent of its variation, while its determinants explain the remaining 29 per cent. Of this 29 per cent, UNEMP explains about 4 per cent, GDP about 1.4 per cent, FOREV about 17 per cent, FODET about 6 per cent and GOVIN assuming the lowest figure of about 0.7 per cent. However, after a period of 10 years, the figures slightly change with the budget deficit explaining about 70 per cent of its own variation, while its economic determinants explain the remaining 30 per cent. The influence of UNEMP slightly decreases to about 3.6 per cent, while GDP remains the same at about 1.4 per cent; with FOREV also remaining at about 17 per cent. FODET also remains the same at about 6 per cent while GOVIN slightly increase to 0.9 per cent. Of all the determinants of budget deficits, FOREV explains the largest component variation over the 10 year period.

\section{Conclusion}

The paper sought to examine the impact of selected macroeconomic variables on budget deficits in South Africa. The vector auto-regression model was used to estimate the respective impact of unemployment, economic growth, foreign reserves, foreign debt, and government investment consumption on the budget deficit. The analyses covered the period 1980 to 2010 using time series annual data. Three broad conclusions can be drawn from the study. Impulse response analysis results suggest that all the determinants of budget deficits, except for foreign debt have a positive impact on budget deficits. Analysis of variance decomposition of budget deficit indicated that foreign reserves explain the largest component variation of budget deficit followed by foreign debt, unemployment, economic growth and government investment, in that order. The variations of budget deficits explained by the selected economic variables are slightly low suggesting that other factors outside those analysed in this study also determine the budget deficit in South Africa. Policy lessons that can be drawn from this study are that budget deficits in South Africa are to an extent a result of macroeconomic problems and imbalances such as highrates of unemployment, low levels of economic growth, foreign reserves, foreign debt and high government investment expenditures.

Studies in the developed world such as the work of Bayar and Smeets (2009) and Agnello and Sousa (2009) examined both economic and political determinants of budget deficits. Such inclusive studies could not specifically attend to and exhaust the individual impact of economic variables. The concentration on economic variables alone as conducted in this study is hugely important for economists who usually have no much control on political variables. It is also imperative to note that there is limited literature regarding to the determinants of budget deficits in the developed world.

\section{References}

Agnello, L., and Sousa, R. M. (2009).The Determinants of Public Deficit Volatility. Working Paper Series No. 1042.

Alogoskoufis, G., and Vander Ploeg, F. (1991).Debts, Deficits and Growth in Interdependent Economies. CEPR Discussion Papers 533. Akinboade, O. A. (2004). The Relationship between Budget Deficit and Interest rates in South Africa: Some Econometric Results. Development Southern Africa, 21(2), 289-302.

Arora, H. and Dua, P. (1993). Budget Deficits, Domestic Investment, and Trade Deficits. Contemporary Policy Issues, 11, 29-44.

Banerjee, A., Galiani, S., Levinsohn, J., Mclaren, Z., and Woolard, I. (2008). Why has unemployment risen in the new South Africa? NBER Working Paper 13167.

Bayar, A. and Smeets, B. (2009). Economic, Political and Institutional Determinants of Budget Deficits in the European Union.CES IFO Working Paper No. 2611.

Blanchard, O. J. (1987). Vector Autoregressive and Reality-Comment. Journal of Business and Economic Statistics, 5(4), 449-451.

Brooks, C. (2002). Introductory Econometrics for Finance.Cambridge University.

Buchanan, J. M., and Tullock, G. (1962). Public Choice Theory. University of Michigan Press.

Du Plessis, S. and Smit, B. (2007). South Africa's growth revival after 1994. Stellenbosch Economic Working Papers: 01/06.

Department of Trade and Industry, (2011).Economic statistics. Reserve bank quarterly bulletin, Selected data[Online] Available http://apps.thedti.gov.za/econdb/default.asp [10 January 2011)

Easterly, W.R., Rodriguez, C.A. and Schmidt-Hebbel, K. (1994). Public Sector Deficits and Macroeconomic Performance.Washington, D.C.; Oxford University Press.

Gujarati, D. (1995). Basic Econometrics: 3rd Edition. McGraw Hill Inc.

Hobbes, T. (2007). The Cambridge Companion to Hobbes's Leviathan. Free University of Bolzano, Italy.

Jacobs, D., Schoeman, N., and Van Heerden, J. (2000). Alternative Definitions of the Budget Deficit and its Impact on the Sustainability of Fiscal Policy in South Africa. University of Pretoria, Pretoria.

Johansen, S. (1991). Estimation and hypothesis testing of co-integration vectors in Gaussian vector autoregressive models. Econometrica 59, 1551-1580.

Johansen, S. (1995).Likelihood-based inference in cointegrated vector autoregressive models. Oxford University Press.

Johansen, S. and Juselius, K. (1990). The Full Information Maximum Likehood Procedure for Inference on Cointegration-With 
Applications to the Demand for Money. Oxford Bulletin of Economics and Statistics, 52, 169-210.

Keynes, J. M. (1936). The General Theory of Employment, Interest, and Money. New York.

Kuştepeli, Y. (2005). The Relationship between Government Size and Economic Growth: Evidence from a Panel Data Analysis. Dokuz Eylül University.

Musgrave, R. (1959). Theory of Fiscal Policy. New York: McGraw Hill.

Pigou, A. C. (1912). Wealth and Welfare. London: Macmillan.

Premchand, A. (1984). Government Budgeting and Expenditure Controls: Theory and Practice. IMF, Washington, D.C.

Ricardo, D. (1817). On the Principles of Political Economy and Taxation.Rod Hay's Archive for the History of Economic Thought, McMaster University, Canada.

Roubini, N.,Sachs, J., Honkapohja, S. and Cohen, D. (1989). Government Spending and Budget Deficits in the Industrial Countries. Economic Policy, 4(8), 100-132.

Saleh, I. (1996). The Impact of the Budget Deficit on Key Macroeconomic Variables in the Major Industrial Countries. PhD Dissertation, Florida Atlantic University.

Smith, A. (1776). An Inquiry into the Nature and Causes of the Wealth of Nations. R. H. Campbell and A. S. Skinner, eds. Liberty Fund: Indianopolis.

National Treasury, (2011). National Budget Review. [Online] Available http://www.treasury.gov.za/documents/nationalbudgetreview [15 September 2011]

\section{Appendices}

Figure 1: Impulse response analysis

Response to Cholesky One S.D. Innovations

Response of $\mathrm{BD}$ to $\mathrm{BD}$

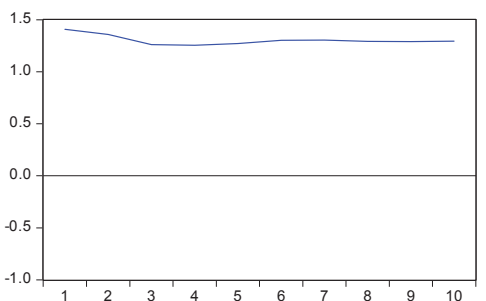

Response of BD to GDP

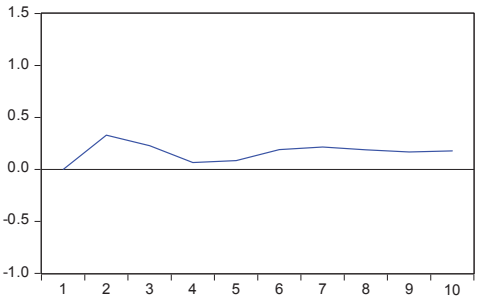

Response of BD to FDEBT

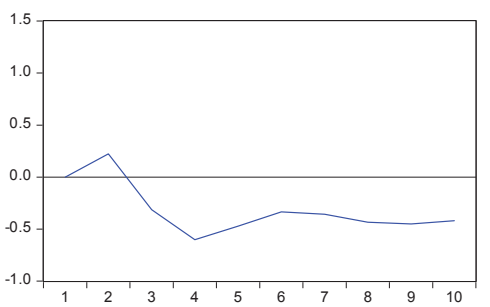

Response of BD to UNEMPL

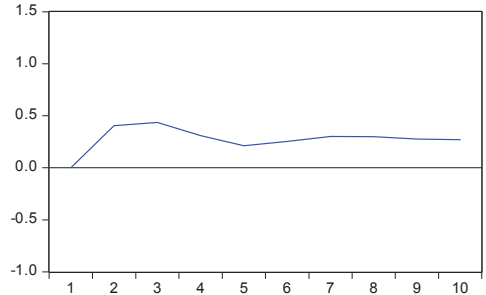

Response of BD to FER

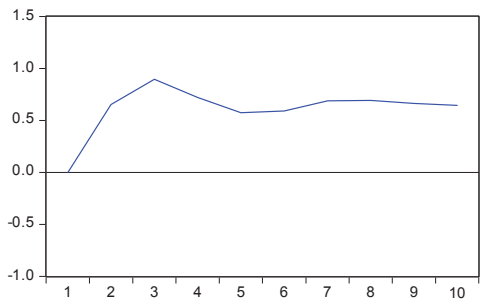

Response of BD to GOVIN

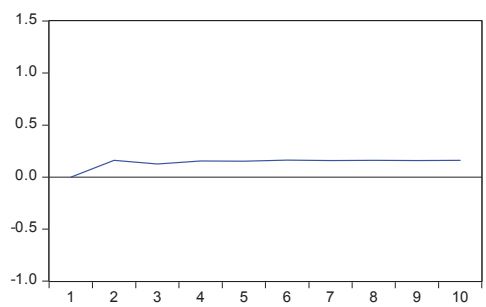


